\title{
Relationship between Service Quality and Customer Delight and Customer Loyalty at the Fitness Center Business in East Java
}

\author{
Ony Thoyib Hadiwijaya ${ }^{1}$, Amiartuti Kusmaningtyas ${ }^{2}$, Abdul Halik ${ }^{2}$ \\ ${ }^{1}$ Doctoral Economic Program Student at Universitas 17 Agustus 1945 Surabaya, Indonesia \\ ${ }^{2}$ Lecturer at Universitas 17 Agustus 1945 Surabaya, Indonesia
}

\section{Abstract}

This article aims to analyze the relationship between Service Quality and Customer Delight and Customer Loyalty at the Fitness Center Business in East Java. This research method This research is an explanatory research. The unit of analysis in this study is the individual. The respondents of this research are members of the Fitness Center in East Java. The population in this study were all fitness members in the East Java region who during 2019-2020 years extended their membership at least twice and were in East Java, especially the Kartosusilo Gate area which includes the cities of Gresik, Bangkalan, Mojokerto, Surabaya, Sidoarjo and Lamongan. The number of sufficient samples is 365 respondents. The results show that Service Quality has no significant effect on customer delight. This is because with standard equipment and services, members feel happy. Likewise, the characteristics of the majority of fitness center members are individuals who feel quite happy with the situation and conditions provided by the manager, thereby indicating that the Service Quality at the current Fitness Center business in East Java has not been able to encourage an increase in customer delight. The results of this study also show that Service Quality has a significant effect on Customer Loyality, thus Service Quality at the current Fitness Center business in East Java can encourage the increase in Customer Loyality. Given the large role of service quality on customer loyalty, it is recommended that companies always maintain and improve service quality at the Fitness Center business in East Java.

\section{Keywords: Service Quality, Customer Delight, Customer Loyalty, Fitness Center}

\section{Introduction}

Many studies prove that the better the quality of service perceived by consumers, the consumers will feel extraordinary satisfaction as an appreciation to the company. According to Kwong and Yau in Raharso (2005), satisfied customers are included in the latent loyalty group, namely those who have a high favorable attitude towards the company but have a low tendency to provide support. Further studies explain the concept of consumer behavior, which describes higher levels of satisfaction. This level will result in more loyalty to the company, which is called "customer delight", (Schlossberg, in Oliver, et al., 1997), Customer Delight as a new strategy will be the key to getting customer loyalty, and customer loyalty is a profit driver for the company. companies ( Christ-Brendemühl \& Schaarschmidt, 2020); Thi et al, 2019; Collier \& Barnes, (2015).; Engel et al., 2006; Keiningham et al, 2001; Schlossberg, 1990).

Another factor that can influence and play an important role so that consumers are satisfied is the competence of the workforce. This is because the workforce is always interacting directly with consumers. Competent and professional workforce will be able to work productively. Employing workers who do not have the competence will clearly pose a big risk to the good name of the place of business. Referring to the opinion of Hoffman \& Bateson (2008), 
measurement of service quality is often done using the SERVQUAL scale. SERVQUAL is based on research done by (Parasuraman in Hoffman (2008), and it is based on five aspects of service quality. These dimensions are as follows: (1) Tangibles (Physical Evidence), which are linked to the attractiveness of physical facilities, equipment, and materials used by the business, as well as the look of workers. (2) Intangibles (Emotional Evidence), which are tied to the attractiveness of personnel. Second, reliability refers to the company's capacity to offer promised services to consumers from the outset without making any errors, as well as the delivery of services in accordance with the agreed-upon time frame. Customer responsiveness (Responsiveness) refers to a service provider's willingness and capacity to react to customer inquiries and offer assistance to consumers.

Customers are also informed about when services will be given by service providers, and services are delivered promptly by service providers. Consumer trust in service providers is fostered by service providers' capacity to act in a way that fosters customer confidence in service providers, and service providers may offer customers with a feeling of security. The assurance provided by service providers, according to Lupioadi (2008), may be understood as a courteous attitude on the part of the provider as well as acquiring the information and abilities required to handle issues and respond to client inquiries. With empathy, service providers may better comprehend their clients' issues and act in their best interests, as well as offer personalized attention to each consumer. In addition, service providers are available at times that are convenient for you.

Customer Delight (customer pleasure) is the reaction of customers when they receive a service or product that provides value beyond their expectations (Mascerenhas, et al in Indriani and Jeysseca, 2011). So in retaining customers the concept of customer delight is very useful because it not only makes customers feel satisfied but also makes customers happy. Prioritizing customers with the concept of delight is expected to make customers more loyal.

According to Cant \& du Toit (2012) loyalty can be defined as an emotional bond with the company by making repeat purchases from time to time and recommending the company to others, even though they have other options. In this case it can be concluded that the understanding of loyalty is actually not only seen from how much customers buy, but from how often customers make repeat purchases and recommend others to buy. Consumer loyalty is the attitude of customers or business partners to use the product consistently, maintain a good image of the product, provide recommendations to other customers to buy the product (Griffin, 2003). This article aims to analyze the Service Quality of Customer Delight and Customer Loyalty at the Fitness Center Business in East Java.

\section{Methods}

According to the definition, this is an explanatory research study, or an explanation-seeking study that seeks to examine theories or hypotheses in order to reinforce or reject current theories or research hypotheses (Cooper \& Emory, 1995:124).

The person is used as the unit of analysis in this research. The participants in this study are members of the Fitness Center in East Java, which conducted the survey. Primary and secondary data were gathered using a cross sectional design, which was used just once in this research. It was necessary to gather research data in person at the study site.

Participants in this research were all fitness members in the East Java region who had renewed their membership at least twice during the 2019-2020 academic year and who lived in East Java, specifically the Kartosusilo Gate area, which encompasses the cities of Gresik, Bangkalan, Mojokerto, Surabaya, Sidoarjo, and Lamongan. The survey was conducted between January and December of 2019. 
According to the Slovin formula, with a tolerance of 5\%, the number of sufficient samples is 365 respondents (according to the formula). Aside from that, a representative sample of respondents is drawn from each sample in an equal proportion.

\section{Service Quality}

According to Tjiptono (2006), "Service quality is the degree of perfection anticipated, as well as the ability to manage the level of excellence in order to fulfill the wishes of the client." These are the indicators of service quality that have been taken from study done by (Parasuraman in Hoffman, 2008) Tangible, Empathy; Responsiveness; Dependability; Assurance.

Customer Delight (also known as customer joy) is the response of consumers when they get a service or product that exceeds their expectations in terms of value (Mascerenhas, et al in Indriani \& Jeysseca, 2011). Kwong \& colleagues (2002) performed research that was utilized to develop the indicators used to assess Customer Delight in (Anindita et al., 2016). The indicators used to evaluate Customer Delight are Justice, Esteem, Security, Trust, and Variety.

\section{Customer Loyalty}

According to Ansori (2014), customer loyalty may be defined as a person's loyalty to a product, which can include both products and certain services. Customers that are very pleased with a specific product or service are known as loyal customers because they are enthusiastic about recommending the product or service to others. According to Kotler \& Keller (2007), the indications used to evaluate consumer loyalty include repurchase, switching across product lines, referring others, and immunity against competitors

\section{Results and Discussion}

Description of Service Quality Variables

Service Quality variable was measured using nine indicators with a total of fifteen items questionnaire items. Description of respondents' assessment of the Service Quality variable is explained as follows:

Table 1. Respondents' Assessment of Service Quality Variable.

\begin{tabular}{|c|c|c|c|c|c|c|c|c|}
\hline Item & STS & TS & $\mathbf{N}$ & $\mathbf{S}$ & SS & Mean & $\begin{array}{c}\text { Indicator } \\
\text { Mean }\end{array}$ & Desc. \\
\hline SQ11 & 34 & 38 & 27 & 111 & 150 & 3,847 & \multirow{3}{*}{3,491} & High \\
\hline SQ12 & 65 & 70 & 92 & 97 & 36 & 2,914 & & Moderate \\
\hline SQ13 & 33 & 33 & 37 & 159 & 98 & 3,711 & & High \\
\hline SQ21 & 35 & 36 & 34 & 182 & 73 & 3,617 & \multirow{3}{*}{3,590} & High \\
\hline SQ22 & 32 & 47 & 37 & 125 & 119 & 3,700 & & High \\
\hline SQ23 & 44 & 56 & 31 & 151 & 78 & 3,453 & & High \\
\hline SQ31 & 36 & 44 & 40 & 151 & 89 & 3,592 & \multirow{3}{*}{3,705} & High \\
\hline SQ32 & 28 & 35 & 26 & 126 & 145 & 3,903 & & High \\
\hline SQ33 & 36 & 44 & 40 & 151 & 89 & 3,619 & & High \\
\hline SQ41 & 14 & 80 & 25 & 125 & 116 & 3,692 & \multirow{3}{*}{3,656} & High \\
\hline SQ42 & 13 & 19 & 10 & 162 & 156 & 4,192 & & High \\
\hline SQ43 & 33 & 126 & 38 & 103 & 60 & 3,086 & & Moderate \\
\hline SQ51 & 25 & 41 & 27 & 173 & 94 & 3,750 & \multirow{3}{*}{3,622} & High \\
\hline SQ52 & 11 & 58 & 45 & 120 & 126 & 3,811 & & High \\
\hline SQ53 & 10 & 97 & 77 & 125 & 51 & 3,306 & & Moderate \\
\hline
\end{tabular}




\begin{tabular}{|c|c|c|c|c|c|c|c|c|}
\hline Item & STS & TS & $\mathbf{N}$ & $\mathbf{S}$ & SS & Mean & $\begin{array}{c}\text { Indicator } \\
\text { Mean }\end{array}$ & Desc. \\
\hline \multicolumn{1}{|c|}{ Variable Mean } \\
\hline
\end{tabular}

Source: Data processed

Table 1. shows that the Service Quality of Fitness Center customers in East Java is perceived as "high", indicated by the average value of 3,613 which is in the range of $3.41-4.20$ (category of "high"). The indicator of the Service Quality variable that was rated the highest by the respondents was SQ42 - Fitness Center Management delivered the fitness program correctly with an average value of 4,192 ("high" category). The indicator of the Service Quality variable that is considered the lowest by the respondent is SQ12 - Clean Fitness Room with an average value of 2,914 (category "medium").

\section{Description of Customer Delight Variables}

The Customer Delight variable was measured using six indicators with a total of nine question items. Description of respondents' assessment of the Customer Delight variable is explained as follows:

Table 2. Respondents' Assessment of Customer Delight Variables

\begin{tabular}{|c|c|c|c|c|c|c|c|c|}
\hline Item & STS & TS & $\mathbf{N}$ & $\mathbf{S}$ & SS & Mean & $\begin{array}{c}\text { Indicator } \\
\text { Mean }\end{array}$ & Dec. \\
\hline CD11 & 18 & 50 & 51 & 162 & 79 & 3,6500 & \multirow{3}{*}{3,707} & High \\
\hline CD12 & 15 & 43 & 55 & 117 & 130 & 3,8444 & & High \\
\hline CD13 & 22 & 67 & 26 & 153 & 92 & 3,6278 & & High \\
\hline CD21 & 11 & 72 & 56 & 150 & 71 & 3,5500 & \multirow{3}{*}{3,532} & High \\
\hline CD22 & 6 & 29 & 43 & 201 & 81 & 3,8944 & & High \\
\hline CD23 & 25 & 111 & 62 & 108 & 54 & 3,1528 & & Moderate \\
\hline CD31 & 21 & 45 & 40 & 196 & 58 & 3,6250 & 3,522 & High \\
\hline CD32 & 6 & 63 & 68 & 141 & 82 & 3,6389 & & High \\
\hline CD33 & 8 & 89 & 88 & 136 & 39 & 3,3028 & & Moderate \\
\hline \multicolumn{7}{|c|}{ Mean Variabel } & 3,587 & High \\
\hline
\end{tabular}

Source: Data processed

Table 2. shows that the Customer Delight of Fitness Center customers in East Java is perceived as "high", which is interpreted as good. This is indicated by the average value of 3,587 which is in the range of $3.41-4.20$ ("high" category). The indicator on the Customer Delight variable that was rated the highest by the respondents was the indicator that my privacy was quite well maintained during the exercise, with an average value of 3.8944 ("high" category). Meanwhile, the Customer Delight indicator that was rated the lowest by the respondents was the item I received attention when I first practiced with an average value of 3.1528 ("high" category).

\section{Description of Customer Loyalty Variables}

The Customer Loyalty variable is measured using six indicators with a total of twelve question items. Description of respondents' assessment of the Customer Loyalty variable is explained as follows: 
Table 3. Respondents' Assessment of Customer Loyalty Variables

\begin{tabular}{|c|c|c|c|c|c|c|c|c|}
\hline Item & STS & TS & $\mathbf{N}$ & $\mathbf{S}$ & SS & Mean & $\begin{array}{c}\text { Indicator } \\
\text { Mean } \\
\end{array}$ & Ket. \\
\hline CL11 & 22 & 40 & 99 & 161 & 38 & 3,4250 & \multirow{3}{*}{3,581} & High \\
\hline CL12 & 18 & 43 & 85 & 132 & 82 & 3,6028 & & High \\
\hline CL13 & 23 & 59 & 25 & 144 & 109 & 3,7139 & & High \\
\hline CL21 & 23 & 64 & 24 & 128 & 121 & 3,7222 & \multirow{3}{*}{3,738} & High \\
\hline CL22 & 21 & 56 & 20 & 139 & 124 & 3,8028 & & High \\
\hline CL23 & 14 & 80 & 28 & 120 & 118 & 3,6889 & & High \\
\hline CL31 & 9 & 58 & 22 & 159 & 112 & 3,8528 & \multirow{3}{*}{3,830} & High \\
\hline CL32 & 8 & 58 & 29 & 154 & 111 & 3,8389 & & High \\
\hline CL33 & 6 & 58 & 42 & 151 & 103 & 3,7972 & & High \\
\hline CL41 & 14 & 76 & 46 & 118 & 106 & 3,6278 & \multirow{3}{*}{3,652} & High \\
\hline CL42 & 18 & 53 & 38 & 136 & 115 & 3,7694 & & High \\
\hline CL43 & 32 & 71 & 28 & 122 & 107 & 3,5583 & & High \\
\hline \multicolumn{7}{|c|}{ Variable Mean } & 3,740 & High \\
\hline
\end{tabular}

Source: Data processed

Table 3. shows that Customer Loyalty of Fitness Center customers in East Java is perceived as "high", which is interpreted as good. This is indicated by the average value of 3,740 which is in the range of $3.41-4.20$ ("high" category). The indicator on the Customer Loyalty variable that is rated the highest by respondents is the indicator I will invite friends to become members at the fitness center, with an average value of 3.8528 ("high" category). Meanwhile, the Customer Loyalty indicator which is considered the lowest by the respondents is the item I regularly renew my membership with an average value of 3,4250 ("high" category).

\section{Service Quality}

The results of the CFA test (Confirmatory Factor Analysis) on service quality variables using Amos 22 software are as follows:

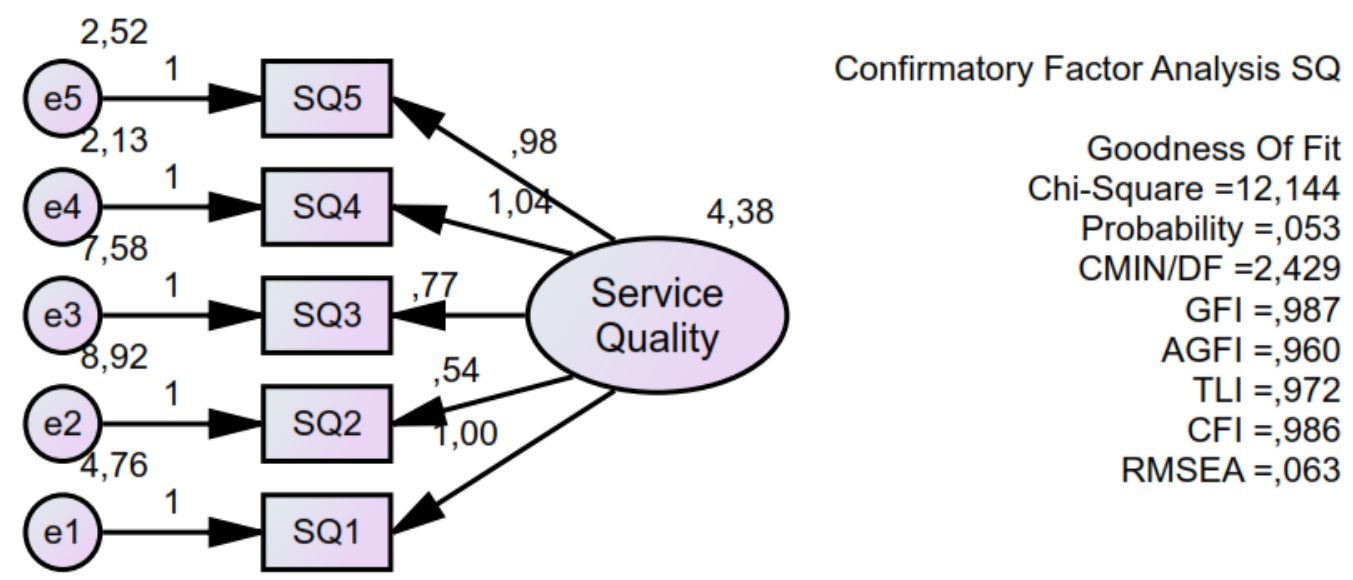

Figure 1. CFA Results on Service Quality

Figure 1. shows that all indicators have a factor loading value greater than 0.50 or $50 \%$, so that these indicators are valid in reflecting the Service Quality variable and can be used for further analysis. The value of GFI (Goodness of Fit Index) with a marginal value of 0.80-0.90 also indicates that the Service Quality construct formed by the indicators is fit with the data.

Copyright (C) 2021, Journal of Asian Multicultural Research for Economy and Management Study, Under the license CC BY-SA 4.0 


\section{Customer Delight}

The results of the CFA test on the Customer Delight variable using the Amos 22 software are as follows:
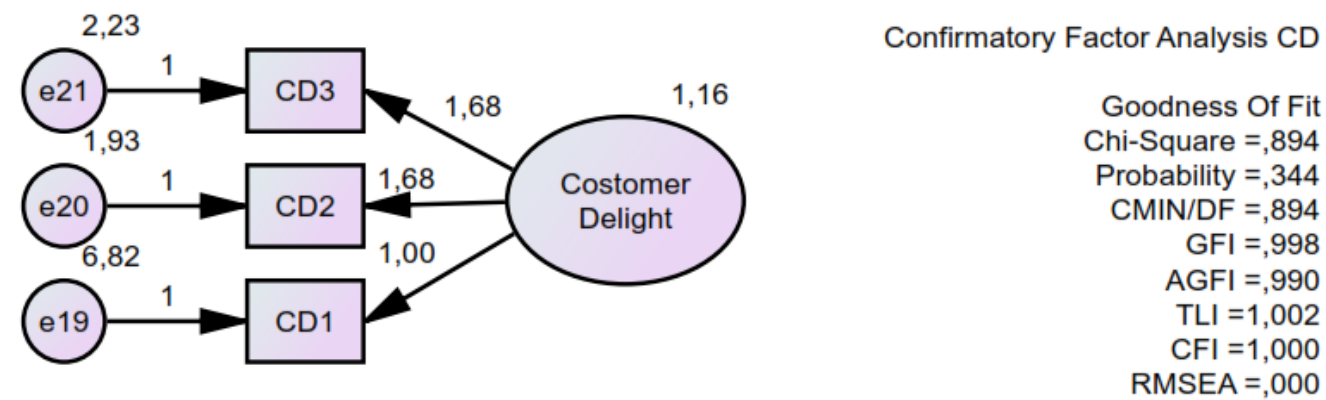

Figure 2. CFA Results on Customer Delight Variables

Figure 2. shows that all indicators have a factor loading value greater than 0.50 or $50 \%$, so that these indicators are valid in reflecting the Customer Delight variable and can be used for further analysis. The GFI (Goodness of Fit Index) value of more than 0.90 also indicates that the competitive advantage construct formed by the indicators is in accordance with the data.

\section{Customer Loyality}

The results of the CFA test on the Customer Loyalty variable using the Amos 22 software are as follows:
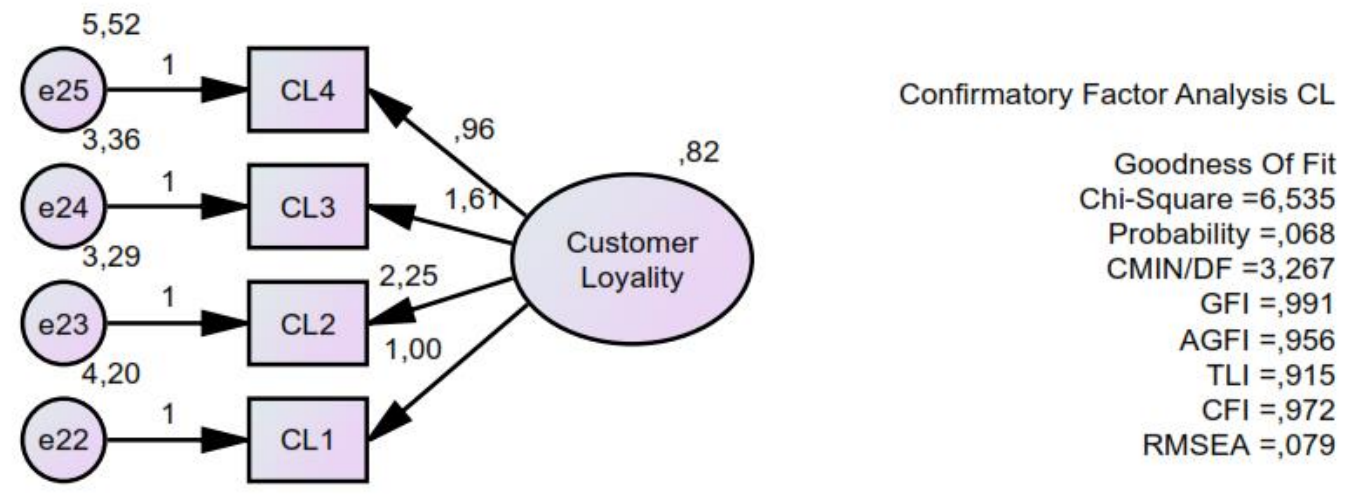

Figure 3. CFA Results on Customer Loyalty Variables

Figure 3. shows that all indicators have a factor loading value greater than 0.50 or $50 \%$, so that these indicators are valid in reflecting the Customer Loyalty variable and can be used for further analysis. The GFI (Goodness of Fit Index) value of more than 0.90 also indicates that the competitive advantage construct formed by the indicators is in accordance with the data.

When the Service Quality variable parameter is estimated on Customer Delight, the findings are statistically insignificant, as shown by a confidence interval (CR) of -0.486 (less than 2.00) and a significance level (p-value) of 0.627. (greater than 5 percent ). In this case, the coefficient of impact is -0.029 (negative), which indicates that Service Quality has no effect on Customer Delight. That Fitness Center Managers in East Java provide excellent service quality and may improve customer satisfaction in the fitness center industry in East Java is also shown by this data. As a result, the first hypothesis, which says that Customer Delight at the Fitness Center in East Java is significantly influenced by Service Quality, cannot be supported.

Statistically significant findings were obtained from the estimation of the Service Quality variable parameter on Customer Loyalty. The confidence interval for the estimate was higher

Copyright $@ 2$ 2021, Journal of Asian Multicultural Research for Economy and Management Study, Under the license CC BY-SA 4.0 
than 2.00, and the significance level (p-value) was 0.000. (less than 5 percent ). Customers' loyalty increases in direct proportion to the quality of service they get, as measured by a coefficient of impact of 0.641 (positive). This also demonstrates that the Customer Loyalty at the Fitness Center in East Java may be improved by providing better service. The second hypothesis, which says that Service Quality has a substantial impact on Customer Loyalty, may thus be regarded as a reasonable conclusion.

Hypothesis testing has shown that there is no statistically significant relationship between Service Quality and Customer Delight. This is due to the fact that members are already satisfied with the basic equipment and services. Similarly, the characteristics of the majority of fitness center members are people who are content with the scenario and circumstances supplied by the facility's supervisor.

Customer Delight is a positive and important factor in the relationship marketing theory, according to the findings of this study. This finding is in contrast to earlier research done by Desiyanti et al, (2018) and Elias-Almeida et al. (2016)., Gusti et al (2020), which found that the

According to the findings of the hypothesis testing, Service Quality has an impact on Customer Loyalty in certain cases. Members are more devoted to a fitness center's existence if it provides them with high-quality service, as shown by studies. As previously stated by Fida et al. (2020). 2020), the findings of this study are in line with the relationship marketing theory and prior research. The findings of this study show that tangibles, responsiveness, dependability, assurance, and empathy have a statistically significant beneficial impact on member loyalty. The findings of Alam \& Noor, (2020). study also showed that customer loyalty is influenced indirectly by the quality of service provided.

\section{Conclusion}

Customer pleasure is not significantly influenced by Service Quality, which indicates that the present Fitness Center company in East Java has not been able to enhance customer happiness as a result of the current Service Quality measures in place. Customer Loyalty is significantly influenced by Service Quality, which suggests that improving Service Quality in the present Fitness Center company in East Java may result in improved Customer Loyalty.

\section{References}

Alam, M. M. D., \& Noor, N. A. M. (2020). The relationship between service quality, corporate image, and customer loyalty of Generation Y: An application of SOR paradigm in the context of superstores in Bangladesh. SAGE Open, 10(2), 2158244020924405.

Anindita, P., Darwin, E., \& Afriwardi, A. (2016). Hubungan Aktivitas Fisik Harian dengan Gangguan Menstruasi pada Mahasiswa Fakultas Kedokteran Universitas Andalas. Jurnal Kesehatan Andalas, 5(3).

Cant, M. C., \& du Toit, M. (2012). Identifying the factors that influence retail customer loyalty and capitalising them. International Business \& Economics Research Journal (IBER), 11(11), 1223-1232.

Christ-Brendemühl, S., \& Schaarschmidt, M. (2020). The impact of service employees' technostress on customer satisfaction and delight: A dyadic analysis. Journal of Business Research, 117, 378-388.

Collier, J. E., \& Barnes, D. C. (2015). Self-service delight: Exploring the hedonic aspects of self-service. Journal of Business Research, 68(5), 986-993. 
Desiyanti, N. L., Sudja, I. N., \& Martini, L. K. B. (2018). Effect of service quality on customer satisfaction, customer delight and customer loyalty (Study on LPD Desa Adat Sembung and LPD Desa Adat Seseh). International Journal of Contemporary Research and Review, 9(03), 20660-20668.

Elias-Almeida, A., Miranda, F. J., \& Almeida, P. (2016). Customer delight: perception of hotel spa consumers. European Journal of Tourism, Hospitality and Recreation, 7(1), 1320.

Engel, J. F., Blackwell, R. D., \& Miniard, P. W. (1995). Consumer behavior.

Fida, B. A., Ahmed, U., Al-Balushi, Y., \& Singh, D. (2020). Impact of service quality on customer loyalty and customer satisfaction in islamic banks in the Sultanate of Oman. Sage Open, 10(2), 2158244020919517.

Griffin, J. (2003). Customer loyalty: menumbuhkan dan mempertahankan pelanggan. Jakarta, Airlangga.

Hoffman \& Bateson. (2011). Service Marketing, International Edition 4e. Colorado State University : Cengage Learning

Keiningham, T. L., Keiningham, T., \& Vavra, T. G. (2001). The customer delight principle: Exceeding customers' expectations for bottom-line success. McGraw Hill Professional.

Kotler, P., \& Keller, K. L. (2007). Manajemen Pemasaran Jilid I (edisi Bahasa Indonesia). Jakarta: PT. Prenhalindo Indonesia.

Oliver, R. L. (1997). Satisfaction: A behavioral perspective on the consumer McGrawHill. International Editions.

Parasuraman, A., Zeithaml, V. A., \& Berry, L. L. (1985). A conceptual model of service quality and its implications for future research. Journal of marketing, 49(4), 41-50.

Raharso, S. (2005). Pengaruh Customer Delight terhadap Behavior-Intention Battery. Jurnal Wirausaha, 34(5), 45-53.

Tjiptono, F. (2008). Strategi Pemasaran. Yogyakarta. Andi Offset. 